\title{
Etkisi
}

\section{The Effects of Anxiety Levels on Burnout Syndrome in Nurses}

\author{
Halil Şengül1', Fadime Çınar'1 ${ }^{1}$, Arzu Bulut ${ }^{2}$ \\ 1İstanbul Sabahattin Zaim Üniversitesi, Sağlık Bilimleri Fakültesi, Sağlık Yönetimi Bölümü, İstanbul, Türkiye \\ 2İstanbul Üsküdar Üniversitesi, Sağlık Bilimleri Enstitüsü, Sağlık Yönetimi, İstanbul, Türkiye
}

\section{$\ddot{O} Z$}

GIRIŞ ve AMAÇ: Fiziksel ve ruhsal nedenler yaşanan, çalışma ortamları olumsuz etkileyen anksiyete ve tükenmişlik sendromu hem bireyi hem de örgütü olumsuz etkileyen kavramlardır. Son zamanlarda yoğun olarak yaşanan bu kavramlar "başaramama, yıpranma, çalışma istek ve arzusunun azalması veya tatmin edilemeyen istekler sonucunda bireyin iç dünyasinda meydana gelen tükenme ile bireyin hayatında gerçekleşen değişimleri ifade etmektedir. Bu araştırma ile yoğun çalışma ortamında bulunan hemşirelerin anksiye düzeyleri ve bu düzeylerin tükenmişlik sendromu ile ilişkisinin varlığını ortaya çıkarmak amaçlandı

YÖNTEM ve GEREÇLER: Araştırmanin evrenini I iki devlet hastanesinde çalışan 387, örneklemini ise 194 hemşire oluşturdu.İlişkisel tipte olan bu araştırma Temmuz 2018-Eylül 2018 tarihleri arasında gerçekleştirildi. Verilerin toplanmasında "Kişisel Bilgi Formu" ile "Beck Anksiyete Ölçeği " ve "Maslach Tükenmişlik Sendromu Ölçeği kullanıldı.Çalışmada; güvenilirlik analizi, bağımsız örneklemler için t testi (independent samples t-test), tek yönlü varyans analizi (one way anova), Tukey çoklu karşılaştırma testi, pearson korelasyon ve regresyon analizleri yapild.

BULGULAR: Çalışmada hemşirelerin duygusal tükenme ve duyarsızlaşma alt boyutları açısından orta, kişisel başarı alt boyutu açısından ise yüksek düzeyde tükenmişlik ve yüksek düzeyde ansiyete yaşadıkları belirlendi

TARTIŞMA ve SONUÇ: Sonuç olarak, hemşirelerin yaşadiğ anksiyete ve buna bağlı bozukluklar, tükenmişlik düzeylerini arttırmaktadır. Sağlık çalışanlarındaki tükenmişlik düzeylerini azaltmaya yönelik olarak yapılacak iyileştirmeler de anksiyete ve buna bağlı bozukluklar göz ardı edilmemeli ve her iki durum içinde gerekli olan iyileştirme faktörleri birlikte harekete geçirilmelidir.

Anahtar Kelimeler: Tükenmişlik sendromu, anksiyete, hemşire

\begin{abstract}
INTRODUCTION: Anxiety and burnout syndrome, which affects physical and mental causes and negatively affects the working environment, are the concepts that negatively affect both the individual and the organization. These concepts, which have been experienced intensively in recent times, refer to the changes in the life of the individual through the depletion in the inner world of the individual as a result of failure, failure, desire to work and diminished desire or desire. The aim of this study was to reveal the anxiety levels of nurses in intensive work environment and the relationship between these levels and burnout syndrome.
\end{abstract}

METHODS: The population of the study consisted of 387 nurses and sample of 194 nurses. This research was conducted between July 2018 and September 2018. "Personal Information Form" and "Beck Anxiety Inventory" and "Maslach Burnout Syndrome Scale" was collected using. In study, reliability analysis, independent samples t-test, one-way ANOVA, Tukey multiple comparison test, pearson correlation and regression analysis were performed.

RESULTS: In the study, it was determined that nurses experienced moderate exhaustion and depersonalization subdimensions, high level of burnout and high level of disability in terms of personal achievement sub-dimension.

DISCUSSION and CONCLUSION: As a result, anxiety and nursing problems of nurses increase burnout levels. Improvements to reduce burnout levels in health care workers should not ignore anxiety and related disorders, and the improvement factors required in both cases should be mobilized together.

Keywords: Burnout syndrome, anxiety, nurse.

İletişim / Correspondence:

Dr. Halil Şengül

İstanbul Sabahattin Zaim Üniversitesi, Sağlık Bilimleri Fakültesi, Sağllk Yönetimi Bölümü, İstanbul, Türkiye

E-mail: halil.sengul@izu.edu.tr

Başvuru Tarihi: 18.07.2019

Kabul Tarihi: 24.08.2019 


\section{INTRODUCTION}

Hospitals are places where work definitions are complex and demands are increasing. Hospitals with unpredictable changes in their daily work routine, are workplaces with high levels of stress due to unrealistic expectations of patients or their relatives and ethical problems. Working conditions in hospitals have been of great concern to health care personnel worldwide (1). Nurses experience heavy workloads in health care systems worldwide (2). In addition to the high level of stress, the pressure of the patients or their relatives frequently encountered by hospital employees or administrative pressures increases the level of anxiety and leads to the development of work-related psychological disorders such as burnout symptoms. Burnout syndrome was defined in health professionals in the early 1970s (3). Delay is a psychological response to interpersonal and emotional stressors in the workplace characterized by emotional exhaustion, depersonalization and lack of personal success. Emotional exhaustion refers to physical and emotional overloads caused by interactions with employees and healthcare users (4). There is no universally accepted definition for burnout syndrome, but many authors believe that Burnout syndrome is a complex form of exhaustion symptoms, leading to desensitization in response to long-term emotional and interpersonal stress in the workplace (5). Emotional exhaustion is defined as employees who are overwhelmed by intensive work tempo and are considered to be the first stage of burnout. Desensitization refers to non-personal feelings about caregivers and reduces personal success, meaning negative self-assessment and reduced perception of achievement in studies with people (6). Burnout syndrome is common among certain professions with high self-sacrifice, motivation and high standards, requiring idealistic commitment to their work such as police, judges, social workers and health workers (5)

The impact and consequences of stress are at the center of many health care studies in the past. Continuous interaction between high professional standards, personal ego integrity and patient needs in the therapeutic relationship leaves the health worker vulnerable to stress, fatigue, and exhaustion. Stress can affect job satisfaction, psychological well-being and physical health (7). For health professionals, the issue of stress has attracted more attention as to investigate the effects of burnout syndrome. Nurses are more sensitive to experiencing burnout than some of the other health professions due to the indirect relationship between job stress and burnout. However, many studies have been conducted to confirm the relationship between stress and burnout in various clinical settings. 8 Stress at the workplace is also a triggering factor in the emergence of anxiety. Anxiety and related disorders are among the most common psychological disorders. The lifetime prevalence of anxiety disorders is $31 \%$ and this prevalence is higher than the prevalence of mood disorders and substance use disorders.9 unfortunately, it has been shown that the diagnosis and treatment of anxiety disorders are insufficient. 10 Anxiety and related disorders cause functional impairment and deterioration in quality of life $(11,12)$. Anxiety has a significant economic impact on the society as it leads to a decrease in work efficiency.13 Persons with anxiety and related disorders have low levels of work productivity and impaired performance $(14,15)$.

Health workers work under high stress due to excessive workload and organizational difficulties, accusations of misapplication and fear of accusation when they do wrong $(16,17)$. The term worry is a complex and loosely defined term that defines a subjective, negative and unpleasant reaction to stress (18). When a person's level of anxiety reaches a level of clinical significance, stress-related disorders begin to emerge. Stress-related disorders include a range of clinical conditions such as neurasthenia, adjustment disorder, burnout, anxiety and depression (19).

The restructuring of health services in Turkey and global budget implementation has led to a reduction in hospital care, and this contributes to increased individual workload for hospital staff. The increase in the individual workload and the consequent increase in the rate of error may lead to increased anxiety and burnout syndrome in health personnel. Although there are many studies on the concept of burnout in health professionals, there are very few 
studies examining the relationship between burnout and anxiety.

In this study, we aimed to draw attention to the fact that anxiety levels should not be ignored in improvement activities to reduce burnout levels by revealing the relationship between the increasing burnout levels and health care workers.

\section{MATERIALS and METHODS}

\section{Purpose and importance of research}

The phenomenon of burnout is one of the issues that researchers have emphasized because it creates great problems both in individual and organizational life.In this study, it was purpose to determine the effect of anxiety levels of nurses on burnout levels and to determine the variables with which these levels are related.In addition, in the light of the data obtained from the study, it was tried to present solutions to prevent anxiety and burnout of nurses.

\section{Model of research}

The measurement model of the 21 indicators related to the effects of anxiety on 22 indicators (observed variable) for three sub factors related to burnout is given below (Figure 1).

Burnout Syndrome

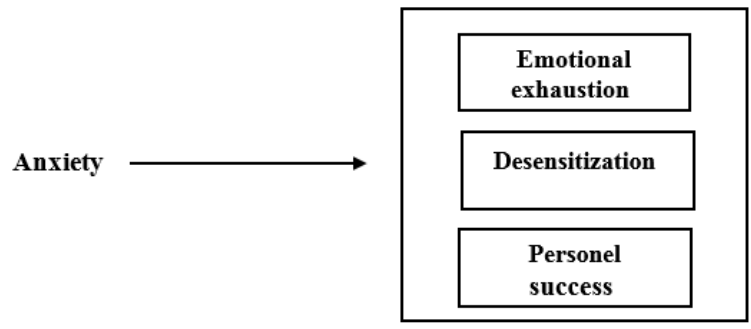

Figure 1. Model of research

\section{Hypothesis of research}

The main hypothesis of the research can be expressed as follows

H1: Nurses' anxiety levels have an impact on their burnout syndrome..

H0: Nurses' anxiety levels have no effect on their burnout syndrome.

\section{Place of research, time, population and sample}

Deterministic and relational type of this research was carried out between July 2018-September 2018. The population of the study consisted of 387 nurses working in two public hospitals operating in the European side of Istanbul. It was aimed to reach the whole universe but due to the voluntary participation and the lack of access to some employees, the research sample was 194 people.

\section{Data collection tools used in research}

The research was conducted in the relational survey model. The literature data developed by the researchers "Personal Information Form" and "Beck Depression Inventory", "Maslach Burnout Syndrome Scale" was collected using $(20,21)$.

Individual Information Form: A total of 6 questions were taken to evaluate the existence of age, gender, marital status, educational status, total working year in the profession and management duty.

Maslach Burnout Scale (MBS): It was developed by Maslach and Jackson in 1981, and in 1992 Turkish validity and reliability study was performed by Ergin.20,22 This scale, which consists of a total of 22 statements, measures burnout in three different dimensions. The first 9 from the expression (1-2-3-6-8-13-14-16-20) resulting emotional exhaustion (EE), the second five, the expression (510-11-15-22) formed depersonalization (D) and the last one is the personal Success (PS) sub-dimension consisting of 8 expressions (4-7-9-12-17-18-19-21). While adapting to Turkish, the 7-digit response options in the original scale were changed to 5 digits $(0=$ Never, $1=$ Very rare, $2=$ Sometimes, $3=$ Most of the time, $4=$ Always). While subscale scores are scored flat for emotional exhaustion and depersonalization, they are scored in reverse for personal success (never $=4$, always $=0$ ). With these scores, the scores between 0-36 for EE, 0-20 for D depersonalization and 0-32 for PA are obtained. The personal success statements in the scale are positive expressions, unlike the others, and the high score from these expressions indicates high personal success and low level of burnout. Accordingly, high scores on emotional exhaustion and depersonalization subscales and lower scores on personal achievement subscale indicate high levels of burnout (Table 1) (23). 


\begin{tabular}{|l|l|l|l|}
\hline \multicolumn{3}{|l|}{ Table 1. Interpretation of Burnout Scale Scores } \\
\hline $\begin{array}{l}\text { Burnout levels } \\
\text { Emotional } \\
\text { exhaustion }\end{array}$ & Low & Normal & High \\
\hline Desensitization & $0-6$ & $17-26$ & 27 and over \\
\hline Personel success & 39 and over & $32-38$ & $0-31$ \\
\hline
\end{tabular}

In the study conducted by Ergin (1992), Cronbach alpha coefficients of the scale were 0.83 for Emotional Exhaustion, 0.72 for Personal Success, and 0.65 for Desensitization.22 In this study, Cronbach's Alpha $(\alpha)$ coefficient for the scale and overall dimensions of internal consistency; Overall reliability of the Maslach Burnout Scale was 0.84; According to the Cronbach Alpha $(\alpha)$ coefficient, the scale was found to be at a very high level of reliability.Emotional Exhaustion Sub-Dimension; $0.86(\alpha)$, Personal Success: $0.77(\alpha)$, Desensitization Sub-Dimension: $73(\alpha)$.

Beck Anxiety Inventory: This inventory is a 21item scale developed by Beck, Epstein, Brown and Streer (1988) to measure anxiety symptoms under the title of Anxiety Disorders in DSM III-R. Turkish adaptation was done in Ulusoy et al.21,24 In the validity and reliability study conducted by Avc1, this scale, which consists of 21 statements, measures burnout in four different dimensions. 25 The first one is Subjective Anxiety (SA) consisting of 9 statements (1-2-3-6-7-8-11-15-19), and the Subjective Fear and its Effects consisting of 5 statements (5-9-14-16-17). Physiological Responses, consisting of Somatic Symptoms (SS) and 2 expressions (18-21), consisting of 5 expressions (4-10-12-13-20), are sub-dimensions. Likert type scale $(0=$ none, $1=$ mild, $2=$ moderate, $3=$ severe) is scored by scoring from 0 to 3 . The highest score is 63. A high total score indicates a high level of anxiety or severity.24 1 to 10 normal, 11-16 moderate mood disorders, 17-20 clinical depression; Moderate depression of 21-30; Severe depression between 31 and 40; 41-63 is considered as severe depression.26 In the study conducted by Avc1, Cronbach's Alpha $(\alpha)$ coefficient for the scale and overall dimensions calculated within the scope of internal consistency; The overall reliability of the Beck Anxiety Inventory was found to be 0.94 . In this study, Cronbach's Alpha $(\alpha)$ coefficient for the scale and overall dimensions of internal consistency; Beck Anxiety Inventory general reliability 0.89; According to Cronbachands Alpha $(\alpha)$ coefficient, the scale was found to be highly reliable. For Subjective Anxiety is 0.86 , for Subjective Fear and Effects 0.77, for Somatic Symptoms 0.75, for Physiological Symptoms 0.78.25

\section{Data Collection Method and Ethical Aspects}

Before starting the research, the permission of the ethics committee (ethics committee approval number: 2018/3) of a university ethics committee and the permission of the senior management of the hospital where the research was conducted were obtained. Verbal and written informed consent was obtained from the nurses included in the study. The researchers gave information about the research and filling the data collection forms.The nurses who accepted to participate in the study were given questionnaires by the distributor and collect method under the control of the researcher and given 1 hour time. This time finally gathered.

\section{Data Analysis}

SPSS 25.0 (Statistical Package for Social Sciences, Chicago, Illinois, United States) statistical program was used for data analysis, mean, percentage and standard deviation values were calculated by descriptive statistical methods.Firstly, Kolmogorov-Smirnov, Shapro Wilk-W test was performed to determine whether the data showed normal distribution and the normal distribution of the data was examined.It was determined that the level of significance was $p>0.05$ and the data showed normal distribution. Parametric tests were performed according to these results.In the comparison of quantitative data, t-test (independent samples t-test), one-way analysis of variance (one way anova), pearson correlation and regression analyzes were performed between two independent groups. Results were evaluated at $95 \%$ confidence interval and $\mathrm{p}$ $<0.05$ significance level.

\section{Limitations of the Study}

The research is limited to the opinions of 194 nurses working in two state hospitals operating in the European side of Istanbul in 2018 and the data obtained from the scale items. 


\section{RESULTS}

The results of the analysis of the descriptive data of the participants included in the study were evaluated. Of the nurses participating in the study,
$53.1 \%$ were female, $46.9 \%$ were male, $82.5 \%$ were graduate, $41.2 \%$ were between $20-30$, and $32 \%$ had 1-3 years of professional experience, $29 \%$ worked in internal clinics (Table 2).

\section{Table 2. Distribution of participants according to demographic characteristics}

\begin{tabular}{|c|c|c|c|}
\hline \multicolumn{2}{|c|}{ Descriptive Characteristics } & Number & $\%$ \\
\hline \multirow[t]{7}{*}{ Working unit } & Emergency department & 32 & 16.5 \\
\hline & Intensive care & 26 & 13.4 \\
\hline & Operating room & 25 & 12.9 \\
\hline & Delivery room & 14 & 7.2 \\
\hline & Internal clinics & 58 & 29.9 \\
\hline & Surgical clinics & 22 & 11.3 \\
\hline & Administrative units & 17 & 9.7 \\
\hline \multirow[t]{5}{*}{ Year of work } & $1-3$ years & 64 & 33.0 \\
\hline & 4-6 years & 10 & 5.2 \\
\hline & $7-10$ years & 22 & 11.3 \\
\hline & $11-15$ years & 52 & 26.8 \\
\hline & 16 years and over & 46 & 23.7 \\
\hline \multirow{5}{*}{$\begin{array}{l}\text { Working time in the } \\
\text { institution }\end{array}$} & $1-3$ years & 94 & 48.5 \\
\hline & 4-6 years & 6 & 3.1 \\
\hline & $7-10$ years & 13 & 6.7 \\
\hline & $11-15$ years & 44 & 22.7 \\
\hline & 16 years and over & 37 & 19.1 \\
\hline \multirow[t]{3}{*}{ Age group } & $20-30$ age from & 80 & 41.2 \\
\hline & $31-40$ age from & 72 & 3.1 \\
\hline & 41 age and over & 42 & 21.7 \\
\hline \multirow[t]{2}{*}{ Gender } & Female & 103 & 53.1 \\
\hline & Male & 91 & 46.9 \\
\hline \multirow[t]{4}{*}{ Education } & High school & 18 & 9.3 \\
\hline & Associate degree & 5 & 2.6 \\
\hline & Graduate & 160 & 82.5 \\
\hline & Postgraduate & 11 & 5.7 \\
\hline \multirow[t]{2}{*}{ Marital status } & The married & 80 & 41.2 \\
\hline & Single & 114 & 58.8 \\
\hline The way it works & $\begin{array}{l}\text { Shiftsless } \\
\text { İn shift }\end{array}$ & $\begin{array}{c}35 \\
159\end{array}$ & $\begin{array}{l}18.0 \\
82.0\end{array}$ \\
\hline
\end{tabular}

In Table 3, the mean score of the Beck Anxiety Inventory $(35.530 \pm 11.49)$ of the nurses participating in the study was as follows: Subject Anxiety $(14.9 \pm 5.41)$; The mean "Subjective Fear and Effects" subscale (7.71 \pm 2.67), "Somatic Symptoms $((8.80 \pm 3.29)$, and Physiological Symptoms $(3.56 \pm 1.50)$ were found.In order to better interpret the results obtained from the data, the highest and lowest scores and the scores of each dimension were evaluated as low, medium and
high.The mean score of lach Maslach Burnout Scale "(60.30 \pm 12.24$)$ and boyut Emotional Exhaustion $(23.16 \pm 8.79)$; the average of the "Desensitization sub-dimension (10.52 \pm 3.46) and personal achievement $((29.15 \pm 5.06)$ were found. 


\begin{tabular}{|l|c|c|c|}
\hline \multicolumn{4}{|l|}{$\begin{array}{l}\text { Table 3. Mean scores of nurses beck anxiety } \\
\text { and maslach burnout scale }\end{array}$} \\
\hline & $\bar{X} \pm \mathrm{SD}$ & Min. & Max. \\
\hline Subjective anxiety & $14.95 \pm 5.41$ & 9 & 29 \\
\hline $\begin{array}{l}\text { Subjective fear } \\
\text { and its effects }\end{array}$ & $7.71 \pm 2.67$ & 5 & 15 \\
\hline Somatic symptoms & $8.80 \pm 3.29$ & 5 & 22 \\
\hline $\begin{array}{l}\text { Physiological } \\
\text { symptoms }\end{array}$ & $3.56 \pm 1.50$ & 2 & 8 \\
\hline $\begin{array}{l}\text { Beck anxiety scale } \\
\text { total }\end{array}$ & $35.04 \pm 11.49$ & 21 & 62 \\
\hline $\begin{array}{l}\text { Emotional } \\
\text { exhaustion }\end{array}$ & $23.16 \pm 8.79$ & 9 & 45 \\
\hline $\begin{array}{l}\text { Desensitization } \\
\text { Personal success }\end{array}$ & $10.52 \pm 3.46$ & 5 & 22 \\
\hline $\begin{array}{l}\text { Maslach burnout } \\
\text { scale total }\end{array}$ & $60.30 \pm 12.24$ & 21 & 91 \\
\hline
\end{tabular}

In Table 4, t-test and one-way analysis of variance (Anova) were performed to determine whether the total scores of Beck Anxiety Inventory and Maslach Burnout Scale scores of the nurses participating in the study showed a significant difference compared to the descriptive variables. The difference between the mean scores according to gender was not statistically significant ( $p>0.05)$. The difference between the mean scores for both scales according to the age variable was found to be statistically significant $(p<0.05)$.Complementary post-hoc analysis was performed in order to determine the sources of the differences and the Beck Anxiety Inventory score of the nurses aged 41 and over was the total score average $(F=14.91 ; p=0.00$ $<0.05)$ and the Maslach Burnout Scale total score average $(F=13.78 ; p=0.00<0.05)$.

According to professional experience, the difference between the mean scores of the Maslach Burnout Scale was statistically significant $(\mathrm{p}<0.05)$. Complementary post-hoc analysis was performed in order to determine the sources of the differences and it was found that the difference was caused by the Maslach Burnout Scale total score average ( $\mathrm{F}=$ $11.69 ; p=0.09<0.05)$ of nurses with 16 years or more experience. There was no statistically significant difference between the mean scores according to the Anche Beck Anxiety Inventory ( $p>$ $0.05)$.

The difference between the mean scores of Beck Anxiety Inventory according to marital status was statistically significant $(\mathrm{p}<0.05)$. Complementary post-hoc analysis was performed to determine the sources of the differences and it was found that the difference was caused by the Beck Anxiety Inventory total score average $(t=2.519 ; p=0.013$ $<0.05$ ) of married nurses. The difference between the mean scores according to Maslach Burnout Scale was not statistically significant ( $p>0.05$ ).

The difference between the groups was statistically significant according to educational status ( $\mathrm{p}<0.05$ ).Complementary post-hoc analysis was performed to determine the sources of the differences and it was found that the difference was caused by the total score average of both scales $(\mathrm{F}=$ 6,$02 ; \mathrm{p}=0.001<0.05$ and $\mathrm{F}=5.20 ; \mathrm{p}=0.001<0.05$ ).

The difference between the mean scores according to the unit variable studied was statistically significant $(\mathrm{p}<0.05)$. Complementary post-hoc analysis was performed to determine the sources of differences and the difference was calculated from the total score of both scales of nurses working in internal units $(F=-7.29 ; p=0.00$ $<0.05$ and $\mathrm{F}=-6.08 ; \mathrm{p}=0.000<0.05)$. It was determined.

The difference between the mean scores was statistically significant ( $\mathrm{p}<0.05$ ).Complementary post-hoc analysis was performed to determine the sources of the differences and it was found that the difference was caused by the mean total score of both scales $(\mathrm{t}=6.11 ; \mathrm{p}=0.006<0.05$ and $\mathrm{t}=11.6 ; \mathrm{p}=$ $0.009<0.05)$.

In Table 5, the relationship between the subdimensions of Beck Anxiety Inventory was evaluated by Spearman-Brown correlation analysis technique and the total score and all sub-dimension scores of the scale were statistically significant $(\mathrm{p}$ $<0.01)$. and $\mathrm{p}<0.05)$. However, there was a statistically significant negative correlation $(\mathrm{p}<0.01$ and $\mathrm{p}<0.05$ ) between personal achievement subdimension and other sub-dimensions and total scale scores of Maslach Burnout Scale.

As shown in table 6, when the effect of nurses' anxiety levels on emotional exhaustion variable is examined, it is seen that anxiety levels have a positive and significant effect on emotional 
Table 4. Nurses Beck anxiety inventory (BAI) and the Maslach burnout inventory (MIBI) based on the demographic characteristics of the difference in their response analysis results

Parameters

\begin{tabular}{|c|c|c|c|c|c|c|}
\hline Gender & $\bar{X} \pm \mathrm{SD}$ & $\mathrm{t}$ & $p$ & $\bar{X}_{ \pm S D}$ & $\mathrm{t}$ & $p$ \\
\hline Male & $33.43 \pm 11.31$ & \multirow[t]{2}{*}{-1.835} & \multirow[t]{2}{*}{.807} & $58.90 \pm 13.25$ & \multirow[t]{2}{*}{-1.510} & \multirow{2}{*}{.122} \\
\hline Female & $36.45 \pm 11.52$ & & & $61.55 \pm 11.20$ & & \\
\hline Age & $\bar{X} \pm \mathrm{SD}$ & $\mathrm{F}$ & $p$ & $\bar{X} \pm S D$ & $F$ & $p$ \\
\hline $20-30$ age from & $31.23 \pm 9.14$ & \multirow{3}{*}{14.91} & \multirow[t]{3}{*}{.000} & $55.49 \pm 13.18$ & \multirow[t]{3}{*}{13.78} & \multirow[t]{3}{*}{.000} \\
\hline $31-40$ age from & $35.08 \pm 11.15$ & & & $62.29 \pm 9.58$ & & \\
\hline 41 age and over & $42.48 \pm 12.78$ & & & $66.34 \pm 11.03$ & & \\
\hline The way it works & $\bar{X}_{ \pm S D}$ & $\mathrm{t}$ & $\mathrm{p}$ & $\bar{X}_{ \pm S D}$ & $\mathrm{t}$ & $p$ \\
\hline İn shift & $18.98 \pm 2.94$ & \multirow[t]{2}{*}{6.11} & \multirow[t]{2}{*}{.006} & $21.60 \pm 3.42$ & \multirow[t]{2}{*}{11.69} & \multirow[t]{2}{*}{.009} \\
\hline Shiftless & $16.53 \pm 3.58$ & & & $19.08 \pm 2.83$ & & \\
\hline Marital status & $\bar{X}_{ \pm S D}$ & $\mathrm{~F}$ & $\mathrm{p}$ & $\bar{X}_{ \pm S D}$ & $\mathrm{~F}$ & $p$ \\
\hline Married & $37.53 \pm 12.08$ & \multirow[t]{2}{*}{2.51} & \multirow[t]{2}{*}{.013} & $64.32 \pm 11.04$ & \multirow[t]{2}{*}{3.96} & \multirow[t]{2}{*}{.968} \\
\hline Single/Divorced & $33.28 \pm 10.78$ & & & $57.49 \pm 12.30$ & & \\
\hline Working unit & $\bar{X}_{ \pm S D}$ & $\mathrm{~F}$ & $p$ & $\bar{X}_{ \pm S D}$ & $\mathrm{~F}$ & $p$ \\
\hline Emergency Department & $26.12 \pm 6.75$ & \multirow[t]{7}{*}{7.29} & \multirow[t]{7}{*}{.000} & $52.34 \pm 12.93$ & \multirow[t]{7}{*}{-6.08} & \multirow[t]{7}{*}{.000} \\
\hline Intensive care & $39.67 \pm 12.03$ & & & $63.03 \pm 11.46$ & & \\
\hline Operating room & $29.40 \pm 6.19$ & & & $51.48 \pm 13.39$ & & \\
\hline Delivery room & $38.07 \pm 11.13$ & & & $60.35 \pm 9.25$ & & \\
\hline Internal Clinics & $39.37 \pm 11.70$ & & & $66.44 \pm 11.07$ & & \\
\hline Surgical Clinics & $32.59 \pm 11.07$ & & & $61.09 \pm 6.42$ & & \\
\hline Administrative units & $21.12 \pm 4.05$ & & & $26.00 \pm 6.93$ & & \\
\hline Year work profession & $\bar{X} \pm \mathrm{SD}$ & $\mathrm{F}$ & $p$ & $\bar{X} \pm S D$ & $\mathrm{~F}$ & $p$ \\
\hline $1-3$ years & $29.93 \pm 7.79$ & \multirow[t]{5}{*}{-7.27} & \multirow[t]{5}{*}{.000} & $52.82 \pm 11.68$ & \multirow[t]{5}{*}{11.11} & \multirow[t]{5}{*}{.000} \\
\hline $4-6$ years & $35.60 \pm 11.54$ & & & $64.90 \pm 17.45$ & & \\
\hline $7-10$ years & $38.40 \pm 10.94$ & & & $65.50 \pm 9.81$ & & \\
\hline $11-15$ years & $34.76 \pm 12.17$ & & & $62.65 \pm 9.86$ & & \\
\hline 16 years and over & $40.71 \pm 12.47$ & & & $64.58 \pm 10.65$ & & \\
\hline Educational background & $\bar{X}_{ \pm S D}$ & $\mathrm{~F}$ & $p$ & $\bar{X}_{ \pm S D}$ & $\mathrm{~F}$ & $p$ \\
\hline High school & $35.50 \pm 11.02$ & \multirow[t]{4}{*}{6.02} & \multirow[t]{4}{*}{.001} & $64.11 \pm 6.7$ & \multirow[t]{4}{*}{5.20} & \multirow[t]{4}{*}{.002} \\
\hline Pre graduate & $55.40 \pm 4.82$ & & & $72.40 \pm 4.27$ & & \\
\hline Graduate & $34.23 \pm 11.32$ & & & $58.88 \pm 12.38$ & & \\
\hline Post graduate & $36.81 \pm 8.60$ & & & $69.27 \pm 12.37$ & & \\
\hline
\end{tabular}

exhaustion $(\beta=-.354)$. In addition, it was observed that anxiety levels of nurses had a positive and significant effect on desensitization $(\beta=.232)$ and burnout syndrome $(\beta=-.317)$. However, the anxiety levels of personal accomplishment $(\beta=-.216)$ appears to be on the negative and significant effect. H1 hypothesis, which is the basis of the research and the findings obtained, has been accepted in this context.

\section{DISCUSSION}

In this study, it was purpose to determine the effect of anxiety levels of nurses on burnout levels and to determine the variables with which these levels are related. The results obtained in our study show that there is a relatively high estimated burnout syndrome and anxiety disorder among nurses (27). These results are similar to the results obtained by other researchers (28). 


\begin{tabular}{|c|c|c|c|c|c|c|c|c|c|c|}
\hline Dimensions & $\bar{X}_{ \pm \mathrm{SD}}$ & 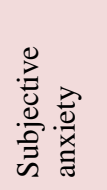 & 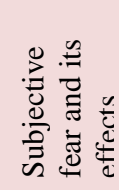 & 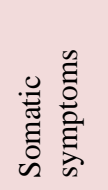 & 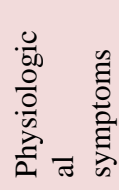 & $\sum_{\infty}^{\infty}$ & 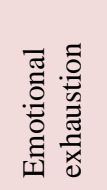 & 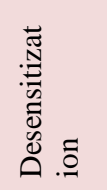 & 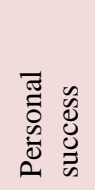 & $\bar{\Sigma}$ \\
\hline Subjective anxiety & $14.95 \pm 5.41$ & 1 & $.199^{*}$ & $.286^{* *}$ & $.920^{* *}$ & $\begin{array}{l}.34 \\
8^{* *}\end{array}$ & $.238^{* *}$ & $.121^{*}$ & $\begin{array}{c}- \\
.168^{*}\end{array}$ & $.628^{* *}$ \\
\hline $\begin{array}{l}\text { Subjective fear and } \\
\text { its effects }\end{array}$ & $7.71 \pm 2.67$ & $.199^{* *}$ & 1 & $.300^{* *}$ & $474^{* *}$ & $\begin{array}{l}.24 \\
1^{* *}\end{array}$ & .152 & $.134^{*}$ & $.149^{*}$ & $.614^{* *}$ \\
\hline Somatic symptoms & $8.80 \pm 3.29$ & $.286^{* *}$ & $.300^{* *}$ & 1 & .562 & $\begin{array}{l}.11 \\
2^{*}\end{array}$ & .238 & $.163^{*}$ & $.104^{*}$ & $.611^{* *}$ \\
\hline $\begin{array}{l}\text { Physiological } \\
\text { symptoms }\end{array}$ & $3.56 \pm 1.50$ & $.920^{* *}$ & $.474^{* *}$ & $.562^{* *}$ & 1 & $\begin{array}{l}.14 \\
2^{* *}\end{array}$ & .267 & $.156^{* *}$ &. & $.502^{* *}$ \\
\hline BAI & $35.04 \pm 11.49$ & $.348^{* *}$ & $.241^{* * *}$ & $.112^{*}$ & $.142^{* *}$ & 1 & $725^{* *}$ & $634^{* *}$ & $.113^{*}$ & $.679^{* *}$ \\
\hline $\begin{array}{l}\text { Emotional } \\
\text { exhaustion }\end{array}$ & $23.16 \pm 8.79$ & $.238^{* *}$ & .152 & $.238^{* *}$ & $.267^{* *}$ & $\underset{* *}{725}$ & 1 & $757^{* *}$ & $.109^{*}$ & $.912^{* *}$ \\
\hline Desensitization & $10.52 \pm 3.46$ & $.121^{* *}$ & $.134^{*}$ & $.163^{* *}$ & $.156^{* *}$ & $\begin{array}{l}.63 \\
4^{* *}\end{array}$ & $757^{* *}$ & 1 & $.102^{*}$ & $.745^{* *}$ \\
\hline Personal success & $29.15 \pm 5.06$ & $-.168^{*}$ & $.149^{*}$ & $-.104^{*}$ & $-.152^{*}$ & $\begin{array}{l}- \\
.11 \\
3^{*}\end{array}$ & $.109^{*}$ & $.102^{*}$ & 1 & $.384^{*}$ \\
\hline MBI & $60.30 \pm 12.24$ & $.628^{* *}$ & $.614^{* *}$ & $.611^{* *}$ & $.502^{* *}$ & .67 & $.912^{* *}$ & $.745^{* *}$ & $.384^{*}$ & 1 \\
\hline \multicolumn{2}{|c|}{ Cronbach alpha reliability coefficient } & 0.86 & 0.77 & 0.75 & 0.78 & $\begin{array}{c}0.8 \\
9\end{array}$ & 0.86 & 0.73 & 0.77 & 0.84 \\
\hline
\end{tabular}

${ }^{* *} p<0.01 .{ }^{*} p<0.05$

Table 6. Regression analysis showing the effect of beck anxiety scale on maslach burnout scale

\begin{tabular}{|c|c|c|c|c|c|c|c|c|}
\hline Regression model & $\begin{array}{l}\text { Independent } \\
\text { variables }\end{array}$ & Dependent variables & $\begin{array}{c}\text { Standard. } \\
\beta\end{array}$ & Sig. & $\mathbf{R}^{2}$ & $\mathbf{t}$ & $\mathbf{F}$ & $\mathbf{p}$ \\
\hline Model 1 & Anxiety & Emotional exhaustion & .354 & $.000^{* *}$ & .053 & -4.509 & 14.218 & $.000^{* *}$ \\
\hline Model 2 & Anxiety & Desensitization & 232 & $.001^{* *}$ & .041 & -.545 & 21.782 & $.000^{* *}$ \\
\hline Model 3 & Anxiety & Personal success & -.216 & $.000^{* *}$ & .071 & -3.834 & 13.631 & $.000^{* *}$ \\
\hline Model 4 & Anxiety & Burnout syndrome & .317 & $.000^{* *}$ & .067 & -4.762 & 17.205 & $.000^{* *}$ \\
\hline
\end{tabular}

When the variables were taken into consideration, it was seen that the anxiety levels of the married people were higher and the marital status did not show a significant difference regarding the level of burnout. Health services are among the high level of stress. A number of responsibilities associated with being married increase the level of stress and consequently the level of anxiety. Age factor, educational factor, working unit and in shift/shiftless increase both anxiety levels and burnout levels. Considering the age variable, both over burnout and anxiety levels increased over the age of 41 years and over 16 years and over in the profession, increased patient burden with health transformation and changing management style influenced health workers caused new pressure on health workers. It can be said that the staff, who are older and with long working life, increased their burnout due to their decreasing anxiety and their expectations from the profession by allowing them to compare the current situation with the old management and a more comfortable working life.29 When the level of education is increased according to the level of education, it is seen that both the level of anxiety and 
the level of burnout increase. This situation can be related to the fact that nurses' tasks become more inquiries as the level of education increases (30).

When an evaluation is made according to the unit variable, the level of anxiety and burnout in the internal units is high. Most of the patients in the internal clinics are chronic patients, long-term hospitalizations, patients in the advanced age group and patients in need of more care, and the patient is in a spirit of satisfaction It can be said that factors such as low number of patients increase anxiety and burnout levels (31). In literature, it is seen that chronic labor force is directly related to depressive symptoms and has a direct effect on depressive symptoms. Although we estimate that anxiety will have a unique effect on each sub-dimension of burnout, it has only been shown to have a negative impact on personal success when it has a positive effect on depersonalization and emotional exhaustion. The study supports the relationship between anxiety and burnout.

This link between job stress and burnout suggests that reducing stressors or adopting effective coping strategies can help reduce burnout prevalence. For example, organizational stressors suggest that when there is a lack of support, emotional support increases levels of depletion, with a reinforced support, it will support the coping strategies of the employee and consequently reduce the negative impact of chronic stress on emotional exhaustion $(32,33)$ A potential mechanism for emotional exhaustion and anxiety. it is also associated with individuality factors such as neuroticism. Anxiety is part of a neurotic personality and there is a correlation between this and emotional exhaustion (34). Neurotic individuals express more negative emotions and express more stress reactions, making them more sensitive to burnout and psychopathology (35). A meta-analytic study has linked anxiety with a neuroticism factor to emotional exhaustion, followed by depersonalization and lowering personal achievement (36) In our study, it was revealed that anxiety increased the perception of personal achievement.

\section{CONCLUSION}

From a practical point of view, interventions and anxiety that are aimed at reducing burnout can be effective, especially the interventions that focus on stress prevention and stress management. A proactive stress prevention approach will help nurses to develop personal resources and improve coping skills to reduce the link between chronic stress, anxiety, and emotional exhaustion. For this approach, personal and environmental resources (eg locus of control, self-confidence, coping strategies, positive outlook, support from colleagues and managers), which are the source of stress, will be defined, strengthened, and will help to reduce initial stress perceptions, increase flexibility, and increase engagement. In addition, the fact that working individuals have a sufficient degree of spiritual emotion, such as compassion, will strengthen strategies to cope with existing beliefs and emotions in the studies to be carried out. Emotions and past stresses of the employees in the past periods, combined with the increasing stressful situations in the health sector, is an increasing problem. Consideration of these interventions will increase the success rates.

\section{REFERENCES}

1. Manyisa ZM, Aswegen EJ. Factors affecting working conditions in public hospitals: A literature review. International Journal of Africa Nursing Sciences. 2017;6:28-38.

2. Shihundla RC, Lebese RT, Maputle MS. Effects of increased nurses' workload on quality documentation of patient information at selected Primary Health Care facilities in Vhembe District, Limpopo Province. Curationis. 2016;39(1):1-8.

3. Maslach C, Schaufeli WB, Leiter MP. Job burnout. Annual Review of Psychology. 2001;52(1):397-422.

4. Guillermo A, CristinaV, Concepción SL, Inmaculada G, Gustavo R, Emilia I. Risk factors and prevalence of burnout syndrome in the nursing profession. International Journal of Nursing Studies. 2015;52(1):240-249.

5. Della EV, DePascale G, Cuccaro A, et al. Burnout: rising interest phenomenon in stressful 
workplace. Annali di İgiene: Medicina Preventiva e di Comunita. 2006;18(2):171-177.

6. Leiter MP, Maslach C. Six areas of worklife: a model of the organizational context of burnout. Journal of Health and Human Services Administration. 1999;21(4):472-489.

7. Raftopoulos V, Charalambous A, Talias M. The factors associated with the burnout syndrome and fatigue in Cypriot nurses: a census report. BMC Public Health. 2012;12(1): 457.

8. Payne N. Occupational stressors and coping as determinants of burnout in female hospice nurses. Journal of Advanced Nursing. 2001;33(3):396-405.

9. Vermani M, Marcus M, Katzman MA. Rates of detection of mood and anxiety disorders in primary care: a descriptive, cross-sectional study. The Primary Care Companion To CNS Disorders, 2011;13(2). doi: 10.4088/PCC.10m01013.

10. Weisberg RB, Dyck I, Culpepper L, Keller MB. Psychiatric treatment in primary care patients with anxiety disorders: a comparison of care received from primary care providers and psychiatrists. American Journal of Psychiatry. 2007;164(2):276-282.

11. Sherbourne CD, Sullivan G, Craske MG, et al. Functioning and disability levels in primary care outpatients with one or more anxiety disorders. Psychological Medicine. 2010;40(12):2059-2068.

12. Comer JS, Blanco C, Hasin DS, et al. Healthrelated quality of life across the anxiety disorders. The Journal of Clinical Psychiatry 2011;72(1):43.

13. Waghorn G, Chant D, White P, Whiteford $\mathrm{H}$. Disability, employment and work performance among people with ICD-10 anxiety disorders. Australian and New Zealand Journal of Psychiatry. 2005;39(1-2):55-66.

14. Katerndahl DA, Realini JP. Quality of life and panic-related work disability in subjects with infrequent panic and panic disorder. The Journal of Clinical Psychiatry. 1997;58(4):153-158.

15. Sanderson K, Tilse E, Nicholson J, Oldenburg B, Graves N. Which presenteeism measures are more sensitive to depression and anxiety? Journal of Affective Disorders. 2007;101(1-3):65-74.
16. Sehlen S, Vordermark D, Schäfer C, et al. Job stress and job satisfaction of physicians, radiographers, nurses and physicists working in radiotherapy: a multicenter analysis by the DEGRO Quality of Life Work Group. Radiation Oncology. 2009;4(1):6.

17. Magnavita N, Fileni A, Magnavita G, et al. Work stress in radiologists. A pilot study. La Radiologia Medica. 2008;113(3):329.

18. Nieuwenhuijsen K, Bruinvels D, FringsDresen M. Psychosocial work environment and stress-related disorders, a systematic review. Occupational Medicine. 2010;60(4):277-286.

19. Castillo RJ, Carlat DJ, Millon T, Millon CM, Meagher S, Grossman S. American Psychiatric Association. (2007). Diagnostic and statistical manual of mental disorders. American Psychiatric Association Press, Washington, DC.

20. Maslach C, Jackson SE. (1981). Manual of Maslach Burnout Inventory. İkinci bask1. California,Consulting Psychologists Press.

21. Beck AT, Epstein N, Brown G, Steer RA. An inventory for measuring clinical anxiety: psychometric properties. Journal of consulting and clinical psychology. 1998;56(6):893.

22. Ergin C. (1992). Doktor ve hemsirelerde tukenmislik ve Maslach tukenmislik olceginin uyarlanmasi. VII. Ulusal Psikoloji Kongresi, 22 Eylül 1992, Ankara.

23. Izgar H. Okul yöneticilerinde tükenmişlik. Nobel Yayın Dağıtım; 2001.

24. McKenzie BC. Medicine and the Internet: Introducing Online Resources and Terminology. 2nd ed. New York, NY: Oxford University Press; 1997.

25. Ulusoy M, Sahin NH, Erkmen H. The beck anxiety inventory: psychometric properties. Journal of Cognitive Psychotherapy. 1998;12(2):163-172.

26. Avcı GM. (1995) Beck anksiyete ölçeğinin geçerlilik ve güvenilirlik çalışması.Yüksek Lisans Tezi. Ege Üniversitesi, Sağlık Bilimleri Enstitüsü, Klinik Psikoloji Bölümü, İzmir.

27. Taycan O, Kutlu L, Çimen S, Aydın N. Bir üniversite hastanesinde çalışan hemşirelerde depresyon ve tükenmişlik düzeyinin 
sosyodemografik özelliklerle ilişkisi. Anadolu Psikiyatri Dergisi. 2006;7(2):100-108.

28. Van Bogaert P, Clarke S, Wouters K, Franck E, Willems R, Mondelaers M. Impacts of unit-level nurse practice environment, workload and burnout on nurse-reported outcomes in psychiatric hospitals: a multilevel modelling approach. International Journal Of Nursing Studies. 2013;50(3):357-365.

29. Demir A, Ulusoy M, Ulusoy MF. Investigation of factors influencing burnout levels in the professional and private lives of nurses. International Journal Of Nursing Studies. 2003;40(8): 807-827.

30. Beer J, Beer J. Burnout and stress, depression and self-esteem of teachers. Psychological Reports. 1992;71(3):1331-1336.

31. Raftopoulos V, Charalambous A, Talias M. The factors associated with the burnout syndrome and fatigue in Cypriot nurses: a census report. BMC Public Health. 2012;12(1): 457.

32. Leiter MP. Coping patterns as predictors of burnout: The function of control and escapist coping patterns. Journal of Organizational Behavior. 1991;12(2):123-144.

33. Leiter M. The dream denied: professional burnout and the constraints of human service organizations. Canadian Psychology/Psychologie Canadienne. 1991;32(4):547.

34. McCrae RR, John OP. An introduction to the five-factor model and its applications. Journal of Personality. 1992;60(2):175-215.

35. Toenjes B, Dickhaeuser O, Kroener S. Goal orientation and lack of achievement in teachers. Zeitschrift Fur Padagogische Psychologie. 2008;22(2):151-160.

36. Watson D, Clark LA, Harkness AR. Structures of personality and their relevance to psychopathology. Journal of Abnormal Psychology. 1994;103(1):18.

37. Deary IJ, Blenkin H, Agius RM, Endler NS, Zealley H, Wood R. Models of job-related stress and personal achievement among consultant doctors. British journal of Psychology. 1996;87(1):3-29. 